\title{
Doğu Gürgeni (Carpinus orientalis Mill.) Fidanlarında Farklı Önişlem ve Yükseltiye Bağlı Olarak Klorofil İçeriğinin Değişimi
}

\author{
Fahrettin ATAR ${ }^{1 *}$, Deniz GÜNEY ${ }^{1}$ \\ ${ }^{1}$ Karadeniz Teknik Üniversitesi, Orman Fakültesi, Orman Mühendisliği Bölümü, 61080, Trabzon
}

\section{Öz}

$\mathrm{Bu}$ çalışmada farklı yükseltilerden elde edilen ve ekim öncesi bazı önişlemlerin uygulandığı tohumlardan yetiştirilen Carpinus orientalis Mill fidanlarına ait yapraklarda, yükselti ve önişlemlere bağlı olarak klorofil içeriklerindeki değişimlerin ortaya konulması amaçlanmıştır. Bitkilerdeki klorofil miktarı yetişme yeri koşulları ve bitki türü başta olmak üzere çeşitli çevresel faktörlere karşı oldukça hassas tepkiler gösterebilmektedir. Çalışma kapsamında Carpinus orientelis'in doğal yayılış alanı içerisindeki Trabzon-Maçka havzasının üç farklı yükseltisinden (0-400 m, 400-800 m, 800-1.200 m) toplanan ve 12 farklı ön işleme tabi tutularak ekimi gerçekleştirilen doğu gürgeni tohumlarından yetiştirilmiş $1+0$ yaşındaki fidanlar kullanılmıştır. Fidanların klorofil içeriği taşınabilir klorofil ölçer (Minolta SPAD-502, Osaka, Japonya) ile ölçülmüştür. Çalışma sonucunda önişlemlerin klorofil değerleri üzerinde istatistiksel olarak anlamlı $(p<0,01)$ bir etkiye sahip olduğu tespit edilmiştir. Yükseltiye bağlı olarak ise klorofil değerleri arasında anlamlı farklılık olmadığı belirlenmiştir. Yapılan ölçümler sonucunda genel itibariyle sitrik asit ile muamele edilen tohumlardan yetişen fidanların klorofil miktarlarının daha fazla olduğu ortaya koyulmuştur.

Anahtar Kelimeler: Klorofil, Minolta, Yaprak, SPAD.

\section{Change of Chlorophyll Content Depending on Different Pretreatment and Elevation in Oriental Hornbeam (Carpinus orientalis Mill.) Seedlings}

\begin{abstract}
In this study, it was aimed to determine the changes in the chlorophyll content of the leaves of the Carpinus orientelis seedlings, which grown from seeds that some pre-treatments are applied before sowing and are obtained from different elevations, depending on the elevation and pretreatment. The amount of chlorophyll in the plant can show very sensitive responses to various environmental factors, especially site conditions and plant species. Within the scope of the study, it was used 1+0 year old seedlings, which grown from seeds that twelve pre-treatments were applied before sowing and were obtained from three elevations (0-400 m, 400-800 m, 800$1,200 \mathrm{~m}$ ). Chlorophyll values of seedlings were measured with portable chlorophyll meter (Minolta SPAD-502, Osaka, Japan). As a result of the study, the significant differences was found between chlorophyll content depending on the pretreatments, while it was found that there was no significant difference between chlorophyll values depending on the altitude. The chlorophyll values of the seedlings grown from the seeds treated with citric acid is higher in general.
\end{abstract}

Keywords: Chlorophyll, Minolta, Leaf, SPAD. 


\section{Giriş}

Carpinus cinsi, ağaç veya çalı formlarına sahip 35-60 türü içermekte olup, kuzey yarımkürenin 1lıman bölgelerinde geniş çapta yayılış göstermektedir (Hora, 1981; Krüssman, 1984). Türkiye’de ise sadece Carpinus orientalis Mill. (doğu gürgeni) ve Carpinus betulus L. (adi gürgen) türlerinin doğal olarak yay1lış1 bulunmaktadır. Carpinus orientalis Avrupa'nın güneydoğusundan İran'ın kuzeyine kadar geniş bir doğal yayılış alanına sahiptir. Ayrıca Carpinus betulus'a göre daha düşük rakımlarda ve çoğunlukla kuru yerlerde bulunmaktadır (Babrov, 1970). Ülkemizde Kuzey Anadolu, Doğu Anadolu, Ege ve Marmara Bölgesin de yayılış gösterir. (Yaltırık, 1982; Demirci, 2006). Doğu gürgeni'nin kuraklık toleransı yüksektir ve genellikle kuru, sığ ve taşlı topraklarda yetişir (Browicz, 1982). Ölüm oranını azaltan kalın kabuk yapısı bu tür için karakteristiktir (Shafiei vd., 2010). Kuraklık stresine dayanıklı olmasından dolayı bozuk alanların rehabilitasyonu için uygun bir türdür (Pipinis vd., 2012). Doğu Gürgeni odunu yoğun olarak yöresel ihtiyaçlarda, turistlik süs eşyalarının yapımında ve yakacak odun olarak kullanılmaktadır (Anşin ve Özkan, 2006).

Carpinus orientalis budamaya uygun bir özellik göstermesi ile canlı çit olarak değerlendirilme ve parkbahçelerde kullanılabilme potansiyeli ve biyolojik çeşitliliğe katkılarından dolayı peyzaj uygulamalarında tercih edilen önemli bir türdür (Güney vd., 2016a). Kentsel yeşil alanlar özellikle şehirde yaşayan insanlar için önemli aktivite alanlarından biridir (Özel ve Ertekin, 2012; Cetin ve Sevik, 2016; Turna, 2017). Bu yeşil alanları oluşturan bitkiler bulundukları ortama estetik değer katmakta ve bu sebeple peyzaj uygulamalarının en önemli parçalarıdır (Cetin vd., 2010; Fallahchai vd., 2013). Peyzaj uygulamalarında kullanılacak bitkilerin seçiminde özellikle bitki yapraklarının sahip oldukları renkler büyük bir öneme sahiptir. Yaprak renklerinin farklılığı gibi, yeşil rengin farklı tonlarına sahip bitkiler de estetik amaçlı kullanımlarda oldukça fazla tercih edilmektedir. Yaprağın içeriğindeki klorofil miktarı yeşil renk tonundaki farklılığın oluşması ile doğrudan ilişkilidir (Kaya vd., 2015; Cetin, 2017).

Heterojen habitatlardaki biyotik ve abiyotik faktörler, bitkilerin yaşamsal (büyüme, üreme ve tohumlama) ve adaptasyon özelliklerini etkilemektedir (Miner vd., 2005; Matesanz vd., 2010). Bitkilerin birçok özelliği ekolojik değişkenlerin mekansal veya zamansal değişiminden etkilenebilir (Shen vd., 2008; Herrera ve Bazaga, 2013). Ekolojik değişkenler, bitkilerin morfolojik, fizyolojik ve anatomik özelliklerinin gelişiminde ve farklı populasyonlar arasındaki adaptasyonda önemli rol oynayabilir (Gianoli ve Valladares, 2010; Nascimbene ve Marini, 2015). Yükseltinin artmasına bağlı iklimsel değişkenlerdeki (sıcaklık, ışık, yağış, vb.) varyasyon, bitkilerin gelişmiş yaşam öyküsü özellikleri ve evrimsel tepkileri ile ilişkilendirilebilir (Aragon vd., 2012; Guerin vd., 2012; Leingartner vd., 2014). Bitkilerdeki klorofil pigmentleri de çeşitli çevresel faktörlere karşı oldukça hassas tepkiler gösterebilmektedir (Lepeduš vd., 2003). Yine tohumlara çimlendirme öncesinde uygulanan çeşitli hormonlar, mikro besinler, vb. işlemlerin bitkilerin klorofil içerikleri üzerinde etkili olduğu birçok çalışmada bildirilmektedir (Onckelen vd., 1977; Pinfield ve Stobart, 1972; Ryc ve Lewak, 1982; Soares vd., 2016).

$\mathrm{Bu}$ çalışmada farklı yükseltilerden elde edilen ve ekim öncesi bazı önişlemlerin uygulandığı tohumlardan yetiştirilen doğu gürgeni fidanlarına ait yapraklarda, yükselti ve önişlemlere bağlı olarak klorofil içeriklerindeki değişimlerin ortaya konulması amaçlanmıştır.

\section{Materyal ve Metot}

\subsection{Materyal}

Araştırmada materyal olarak doğu gürgeninin (Carpinus orientalis Mill.) doğal yayılış alanı içerisindeki Trabzon-Maçka havzasının üç farklı yükseltisinden (0-400 m, 400-800 m, 800-1200 m) toplanan (Şekil 1) ve 12 farklı ön işleme tabi tutularak ekimi gerçekleştirilen tohumlardan yetiştirilmiş $1+0$ yaşındaki fỉdanlar kullanılmıştır. Çimlenme engelinin giderilmesi amacıyla giberellik asit (100 ppm, 250 ppm, 500 ppm) ile 10 dakika muamele, sitrik asit (5000 ppm, 10000 ppm, 15000 ppm) ile 5 gün muamele, sülfirik asit (\%95-97) ile 30, 60 ve 180 dakika muamele, kanatlı ekim, tohum ucu kesilerek ekim ve kontrol olmak üzere tohumlara 12 farklı önişlem uygulanmıştır. Karadeniz Teknik Üniversitesi Orman Fakültesi Araştırma ve Uygulama Serasına ait açık alan koşullarındaki yastıklarda yetiştiren 1+0 yaşındaki doğu gürgeni fidanlarının yaprakları kullanılarak klorofil miktarları ölçülmüştür. Ayrıca Karadeniz Teknik Üniversitesi'nin bulunduğu Trabzon iline ait 1927-2018 yılları arası iklim verileri Tablo 1'de verilmiştir. Açık alan fidanlığının yer aldığı bölgenin uzun vadeli iklim verilerine göre yıllık ortalama sıcaklık 14,7 olup yıllık toplam yă̆ış 829,6 mm'dir. 


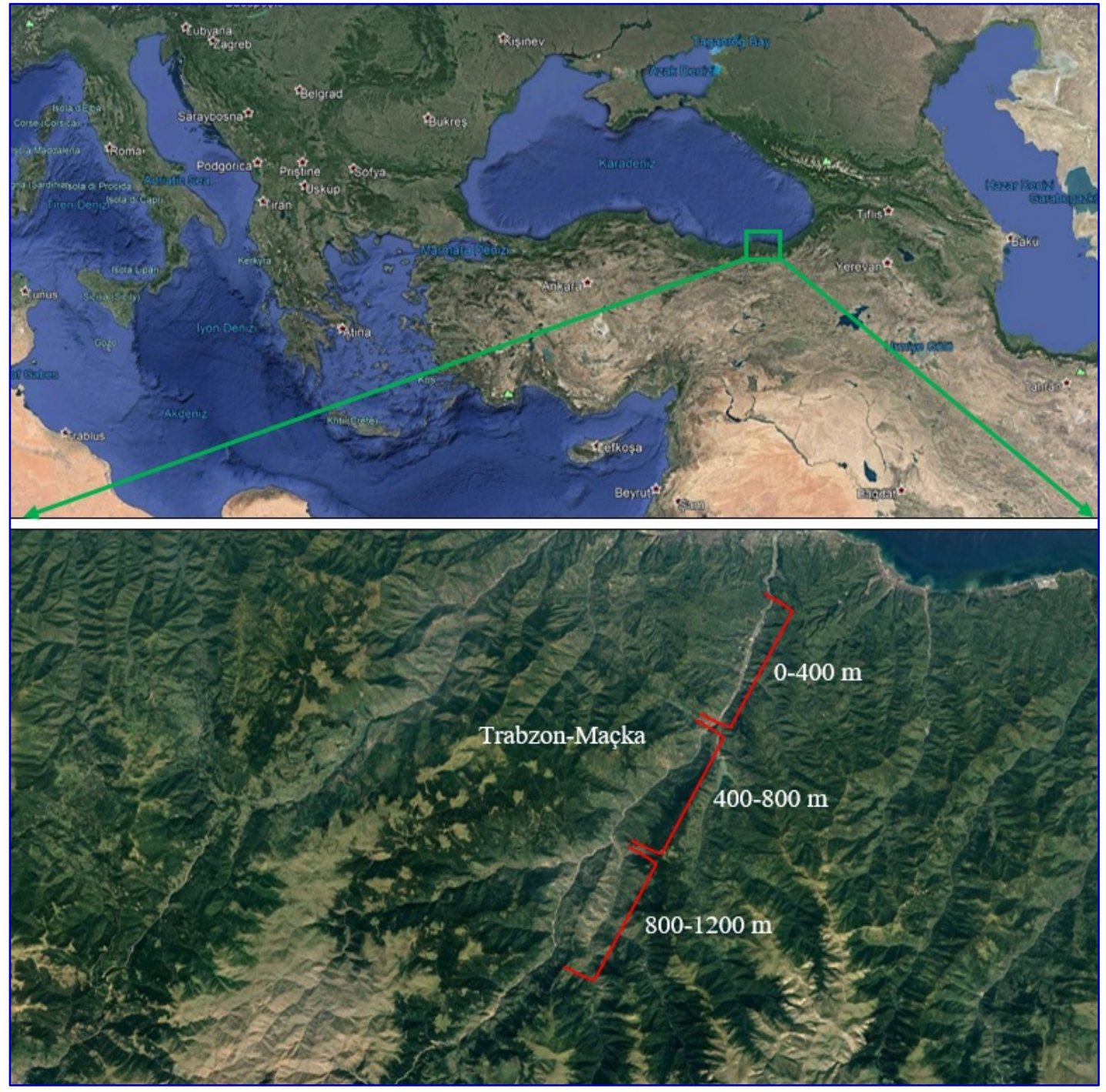

Şekil 1. Tohumların elde edildiği yükselti kuşağını gösteren harita.

Tablo 1. Çalışma alanına ait ortalama meteorolojik veriler.

\begin{tabular}{ccccccccccccc}
\hline \multicolumn{10}{c}{ İklim Periyodu (1927-2019) } \\
\hline & Oca & Şub & Mar & Nis & May & Haz & Tem & Ăgu & Eyl & Eki & Kas & Ara \\
\hline $\mathbf{1}$ & 7.4 & 7.2 & 8.3 & 11.7 & 15.8 & 20.1 & 22.9 & 23.3 & 20.3 & 16.6 & 12.9 & 9.5 \\
$\mathbf{2}$ & 10.7 & 10.7 & 11.9 & 15.5 & 19.1 & 23.1 & 25.9 & 26.5 & 23.7 & 20.0 & 16.5 & 12.9 \\
$\mathbf{3}$ & 4.6 & 4.3 & 5.4 & 8.6 & 12.9 & 17.0 & 19.9 & 20.3 & 17.3 & 13.6 & 10.0 & 6.7 \\
$\mathbf{4}$ & 2.6 & 3.2 & 3.4 & 4.3 & 5.5 & 7.0 & 5.9 & 5.6 & 4.9 & 4.5 & 3.6 & 2.6 \\
$\mathbf{5}$ & 11.8 & 11.7 & 12.6 & 12.4 & 12.3 & 10.3 & 7.6 & 8.3 & 10.4 & 11.8 & 11.3 & 12.0 \\
$\mathbf{6}$ & 82.9 & 64.6 & 58.4 & 56.9 & 52.1 & 51.8 & 35.6 & 48.0 & 78.6 & 115.4 & 99.6 & 85.7 \\
\hline
\end{tabular}

1. Ort. Sıcaklık $\left({ }^{\circ} \mathrm{C}\right) ; 2$. Ort. En Yüksek Sicaklık $\left({ }^{\circ} \mathrm{C}\right)$; 3. Ort. En Düşük Sıcaklık $\left({ }^{\circ} \mathrm{C}\right)$;

4.Ort. Güneşlenme Süresi (hour); 5. Ort.. Yağışlı Gün Sayısı; 6. Aylık Toplam Yağış Miktarı Ortalaması. (mm)

\subsection{Metot}

Klorofil içeriği, yapraktaki klorofil miktarını dolaylı olarak ölçen, taşınabilir klorofil metre cihazı (Minolta SPAD-502, Osaka, Japan) ile tespit edilmiştir. Ölçümler her bir populasyona ve önişleme ait 30 fidanın yapraklarında yapılmıştır. Klorofil ölçümü, bir yaprakta üç kere ölçüm (yaprağın ucu, ortası ve sapa yakın k1smından) yapılıp ortalama klorofil konsatrasyon indeksi (CCI-Chlorophyll Concentration Index) değeri alınarak belirlenmiştir. Klorofil metre Inada’nın (1963) prensipleri ile dizayn edilerek üretilmiştir. Relatif klorofil 
yoğunluğunu yaprak dokusundaki kırmızı ve infraed bölgeleri (sırasıyla 659nm ve $940 \mathrm{~nm}$ dalga boyunda) ölçüm yaparak belirlemektedir.

Elde edilen veriler SPSS 20.0 istatistik paket programı kullanılarak analiz edilmiştir. Çalışmada farklı populasyon ve önişlemlere bağlı olarak klorofil içeriğinin değişiminin istatistiksel olarak anlamlılığını ortaya koymak için varyans analizi (one-way ANOVA) yapılmıştır. Varyans analizi sonucu anlamlı farklılıkların bulunması durumunda, populasyon ve önişlemlerin meydana getirdiği grupları belirlemek amacıyla Duncan testi yapılmıştır.

\section{Bulgular ve Tartışma}

Çalışmada ekim öncesinde tohumlara uygulanan önişlemler sonrasında elde edilen $1+0$ yaşındaki doğu gürgeni fidanlarında klorofil içerikleri tespit edilerek önişlemlere bağlı olarak değişimi ortaya koyulmuştur. Yapılan ölçümler neticesinde klorofil içeriğine ilişkin minimum, maksimum, ortalama ve standart sapma değerleri belirlenmiş olup, sonuçlar Tablo 2'de verilmiştir.

Tablo 2. Farklı önişlemlere bağlı olarak klorofil içeriğine ait sonuçlar.

\begin{tabular}{|c|c|c|c|}
\hline Önişlem & Min. (CCI) & Mak. (CCI) & Ort \pm Std. sapma (CCI) \\
\hline Kontrol & 23.80 & 46.30 & $36.27 \pm 5.29$ \\
\hline Kanatlı ekim & 27.20 & 41.80 & $33.30 \pm 3.53$ \\
\hline Tohum ucu kesilerek ekim & 31.80 & 41.30 & $37.24 \pm 2.67$ \\
\hline GA 100 ppm & 24.20 & 43.00 & $35.37 \pm 4.28$ \\
\hline $\mathrm{GA}_{3} 250 \mathrm{ppm}$ & 27.70 & 43.40 & $35.36 \pm 4.25$ \\
\hline $\mathrm{GA}_{3} 500 \mathrm{ppm}$ & 24.60 & 45.80 & $36.14 \pm 5.11$ \\
\hline $\mathrm{H}_{2} \mathrm{SO}_{4} 30$ dk. & 26.90 & 40.10 & $34.75 \pm 3.67$ \\
\hline $\mathrm{H}_{2} \mathrm{SO}_{4} 60$ dk. & 25.80 & 42.40 & $35.22 \pm 3.83$ \\
\hline $\mathrm{H}_{2} \mathrm{SO}_{4} 180$ dk. & 25.30 & 47.30 & $38.12 \pm 4.69$ \\
\hline Sitrik Asit 5000 ppm & 33.80 & 42.40 & $37.89 \pm 2.47$ \\
\hline Sitrik Asit 10000 ppm & 31.50 & 43.40 & $37.84 \pm 3.09$ \\
\hline Sitrik Asit 15000 ppm & 26.10 & 41.10 & $36.14 \pm 3.79$ \\
\hline
\end{tabular}

Önişlemlere bağlı olarak klorofil değerlerine ait sonuçlar incelendiğinde, minimum klorofil değeri 23.80 CCI ile "kontrol" işleminde, maksimum klorofil değeri ise $47.30 \mathrm{CCI}$ ile " $\mathrm{H}_{2} \mathrm{SO}_{4} 180 \mathrm{dk}$." işleminde tespit edilmiştir. Ortalama klorofil değerleri 33.30 CCI ve 38.12 CCI arasındadır ve en yüksek klorofil değeri " $\mathrm{H}_{2} \mathrm{SO}_{4} 180$ dk." işleminde elde edilmiştir. "Sitrik asit 5000 ppm" ve "Sitrik asit 10000 ppm" işlemlerine ait fidanların klorofil değerleri ikinci ve üçüncü en yüksek değere sahip olmuştur.

Üç farklı yükseltiden elde edilen tohumlardan yetiştirilen fidanlara ait yaprakların klorofil içerikleri belirlenmiş ve yükseltiye bağlı olarak klorofil içeriklerinin minimum, maksimum, ortalama ve standart sapma değerleri Tablo 3'te gösterilmiştir. Buna göre her üç yükselti kuşağına ait klorofil değerlerinin birbirlerine çok yakın olduğu, en yüksek ortalama klorofil değeri 34.12 CCI ile "400-800 m” yükseltiye ait fidanlarda, en düşük ortalama klorofil değeri ise $33.84 \mathrm{CCI}$ ile "0-400 m” yükseltiye ait fidanlarda belirlemiştir.

Tablo 3. Farklı yükseltiye bağlı olarak klorofil içeriğine ait sonuçlar

\begin{tabular}{lccc}
\hline Yükselti & Min. (CCI) & Mak. (CCI) & Ort \pm Std. sapma (CCI) \\
\hline $\mathbf{0 - 4 0 0 ~} \mathbf{~ m}$ & 22,50 & 40,90 & $33.84 \pm 3.99$ \\
$\mathbf{4 0 0 - 8 0 0 ~} \mathbf{~ m}$ & 25,70 & 40,10 & $34.12 \pm 3.65$ \\
$\mathbf{8 0 0 - 1 2 0 0 ~} \mathbf{~ m}$ & 15,90 & 41,00 & $33.98 \pm 4.61$ \\
\hline
\end{tabular}

Farklı önişlem ve yükseltiye bağlı olarak klorofil değerleri arasındaki farkların istatistiksel olarak anlamlılığını ortaya koymak amacıyla varyans analizi (one-way ANOVA) yapılmış ve elde edilen sonuçlar Tablo 4'te verilmiştir. Yapılan varyans analizi sonucunda önişlemlere ilişkin klorofil değerleri arasında istatistiksel olarak 
\%99 güven düzeyinde $(p<0,01)$ anlamlı farklılıkların olduğu tespit edilmiştir. Üç farklı yükseltiye bağlı olarak klorofil değerleri arasında ise istatistiksel olarak anlamlı farklılıkların bulunmadığı $(p>0,05)$ belirlenmiştir.

Tablo 4. Klorofil içeriğine ait varyans (one-way ANOVA) analizi sonuçları.

\begin{tabular}{llccccc}
\hline & & $\begin{array}{c}\text { Kareler } \\
\text { toplamı }\end{array}$ & $\begin{array}{c}\text { Serbestlik } \\
\text { derecesi }\end{array}$ & $\begin{array}{c}\text { Kareler } \\
\text { ortalaması }\end{array}$ & F & P \\
\hline \multirow{3}{*}{ Önişlem } & Gruplar arası & 694,751 & 11 & 63,159 & 3,975 & $0,000^{*}$ \\
& Gruplar içi & 5529,651 & 348 & 15,890 & & \\
\hline \multirow{3}{*}{ Yükselti } & Toplam & 6224,401 & 359 & & & 0,966 \\
& Gruplar arası & 1,180 & 2 &, 590 & 0,035 & \\
& Gruplar içi & 1467,639 & 87 & 16,869 & & \\
\hline
\end{tabular}

${ }^{*} p<0.01: \% 99$ güven düzeyinde istatistiksel olarak anlamlı fark vardır.

Varyans analizi sonucunda önişlemlere ilişkin klorofil değerleri arasında istatistiksel olarak anlamlı farklılıkların bulunmasından dolayı, Duncan testi ile önişlemlerin meydana getirdiği gruplar ortaya koyulmuştur (Şekil 2). Buna göre Duncan testi sonucunda önişlemler arasında altı farklı grup oluşmuştur. Klorofil içeriği bakımından en yüksek değerleri alan " $\mathrm{H}_{2} \mathrm{SO}_{4} 180$ dk.", "sitrik asit 5000 ppm" ve "sitrik asit 10000 ppm” işlemleri ilk grubu meydana getirmiştir. Üçüncü grupta "sitrik asit 15000 ppm”, "GA 500 ppm” ve "kontrol” işlemi yer almıştır. “ $\mathrm{H}_{2} \mathrm{SO}_{4} 60$ dk.”, “GA 3100 ppm” ve “GA 250 ppm” işlemleri dördüncü grubu oluşturmuşlardır. Diğer işlemler ise tek başlarına farklı gruplarda yer almışlardır.

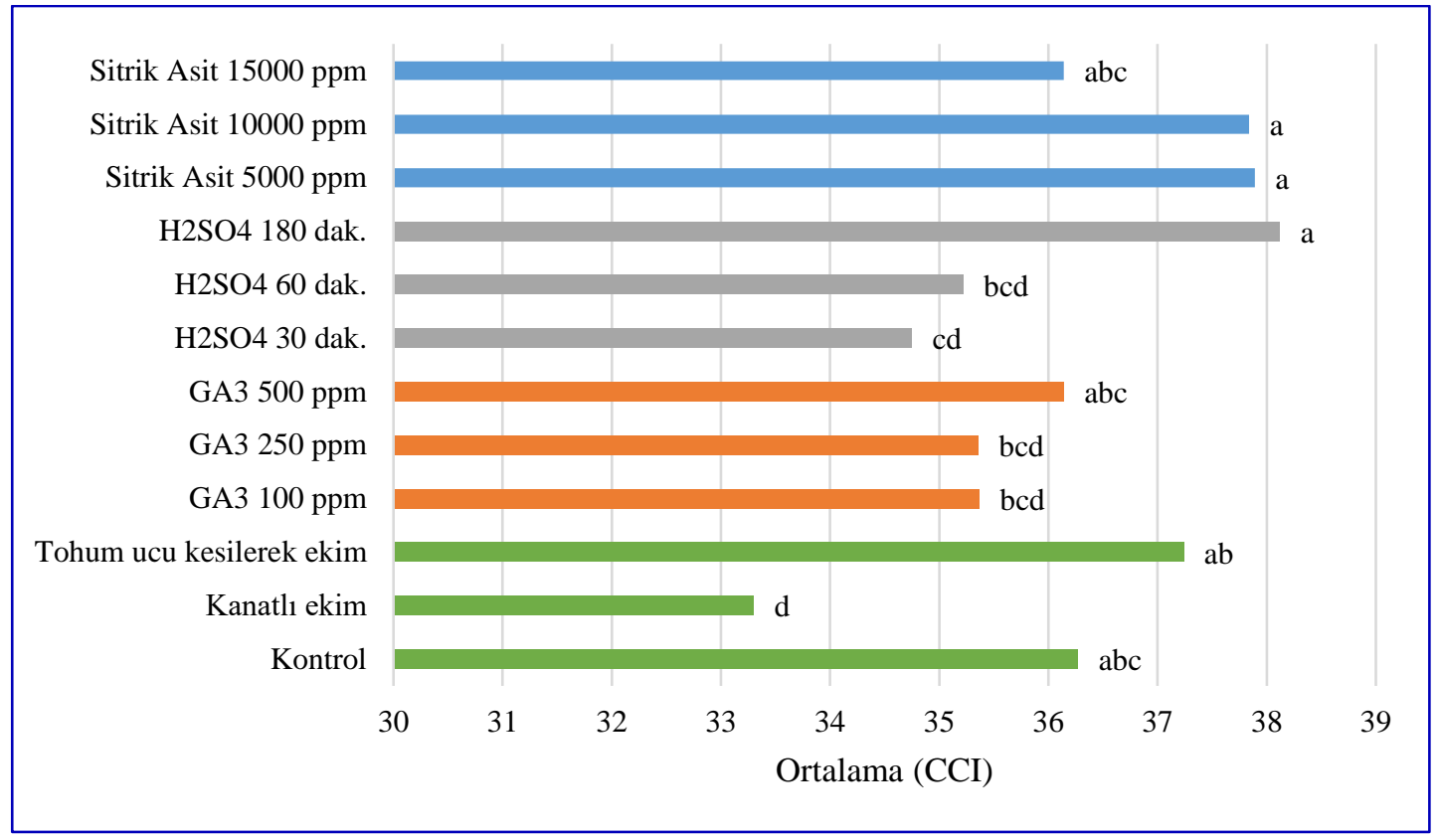

Şekil 2. Önişlemlere ilişkin klorofil içeriklerine ait Duncan testi sonuçları.

Yapılan çalışmada uygulanan önişlemler gruplandırılarak, klorofil içeriği üzerine etkileri ortaya konulmaya çalışılmıştır. Bu kapsamda sitrik asit $(5000,10000,15000$ ppm), giberellik asit $(100,250,500$ ppm) ve sülfirik asit $(30,60,180 \mathrm{dk}$.) işlemlerine ait klorofil değerlerinin ortalamaları ile kimyasal önişlem uygulanmayan "kontrol, kanatlı ekim ve tohum ucu kesilerek ekim" işlemlerine ait klorofil değerlerinin ortalamaları kıyaslanarak sonuçlar Şekil 3'te gösterilmiştir. Buna göre en yüksek ortalama klorofil değeri sitrik asit işlemine ait fidanlarda elde edilirken, bunu sülfirik asit işlemi uygulanan fidanlar takip etmiştir. En düşük ortalama klorofil değeri ile kimyasal önişlem uygulanmayan fidanlarda elde edilmiştir. 


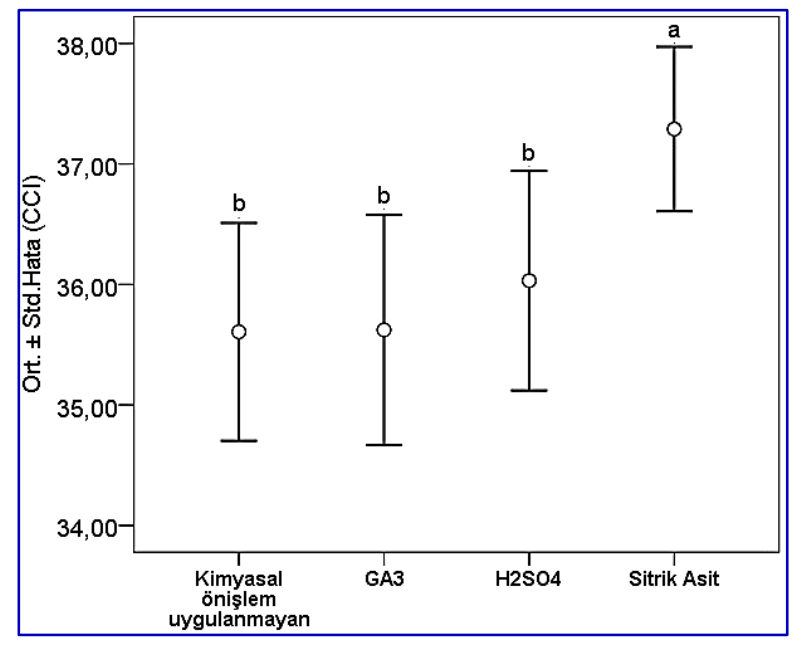

Şekil 3. Önişlemlere ilişkin klorofil içeriklerine ait Duncan testi sonuçları.

\section{Tartışma ve Sonuç}

Bitkilere ait morfolojik, fizyolojik, anatomik ve fenolojik özellikler arasındaki farklılıklar genetik yapıya bağlı olduğu gibi, bu özelliklerin çevresel faktörlere bağlı olarak da değiştiği bilinmektedir (Güney vd., 2016b; Atar ve Turna, 2018; Atar vd., 2020). Yapraklardaki klorofil içeriğinin de pek çok çevresel faktörden etkilenerek değişiklik gösterdiğini bildiren birçok çalışma mevcuttur (Gond vd., 2012; Atar vd., 2013; Kaya vd., 2015). Bitkilerin klorofil miktarlarının farklılık göstermesindeki en önemli etken diğer tüm karakterlerde olduğu gibi genetik yapıdır (Taner ve Sade, 2005). Ayrıca yaprak yapısının da klorofil miktarını belirleyen önemli etkenlerden olduğu belirtilmektedir. Tepe vd. (2002), poliploid bitkilerin klorofil miktarının diploidlere göre daha fazla olduğunu ve bu nedenle bu bitkilerin yapraklarının koyu yeşil renkli olduğunu bildirmiştir. Yapılan çalışmada açık alan koşullarında yetiştirilmiş $1+0$ yaşındaki doğu gürgeni fidanlarına ait klorofil değerlerinin farklı önişlemler ve yükseltiye bağlı olarak değişimleri ortaya koyulmuş̧ur.

Farklı önişlemler uygulanarak ekimi gerçekleştirilen tohumlardan elde edilen fidanlara ait klorofil değerleri arasında istatistiksel olarak anlamlı farklılıkların olduğu tespit edilmiştir. Yapılan ölçümler sonucunda genel itibariyle sitrik asit ile muamele edilen tohumlardan yetişen fidanların klorofil miktarlarının daha fazla olduğu ve ekim öncesi tohumlara uygulanan önişlemlerin klorofil değerleri üzerinde anlamlı bir etkiye sahip olduğu ortaya koyulmuştur. Çalışma sonuçlarına benzer şekilde, Soares vd. (2016) tarafından soya fasulyesinin fizyolojik özellikleri üzerine mikro besin, aminoasit ve hormonların etkilerinin araştırıldığı bir çalışmada mikro besinler, hormonlar ve aminoasitler ile muamele edilen tohumlardan yetişen soya fasulyesinin klorofil içeriğinin kontrol işlemine kıyasla \%58 daha fazla olduğu bildirilmiş̧ir. Ayrıca SPAD indeksindeki artışı, bitkilerin daha yüksek net fotosentezine yansıdığı belirtilmiştir. Pinfield ve Stobart (1972) tarafından Acer pseudoplatanus (L.) türünde çimlenmenin hormonal düzenlenmesi ve erken fide gelişimi üzerine yapılan diğer bir çalışmada, su, kinetin ve gibberellin içinde 10 gün inkübe edilmiş izole embriyolardan yetiştirilen fidelere ait kotiledonların klorofil içeriği arasında önemli farklılıkların olduğu ortaya konulmuştur. Uyku halinde ve katlamaya alınmış Malus domestica embriyolarında fotosentez mekanizmalarının oluşumu üzerine hormonların etkisinin araştırıldığı başka bir çalışmada, giberellin, kinetin ve absisik asit ile uygulamalarının klorofil içeriği üzerine etkili olduğu belirtilmiştir (Ryc ve Lewak, 1982). Onckelen vd. (1977) Phaseolus vulgaris L. kotiledonlarında $\alpha$ ve $\beta$ amilaz aktiviteleri üzerine 1şık şiddeti ve endojen büyüme hormonlarının etkisini ortaya koyarak, klorofil içeriğinde şiddetli bir artış ve endojen giberellin-inhibitör dengesinde değişiklik olduğunu bildirilmiştir. Üç farklı yükseltiden toplanan tohumlardan yetiştirilmiş $1+0$ yaşındaki fidanlara ait klorofil değerleri arasında istatistiksel olarak anlamlı farklılıkların bulunmadığı belirlenmiştir. Atar vd. (2013) tarafından yapılan bir çalışmada, dört farklı havza ve üç farklı yükseltiye ait tohumlardan yetiştirilen adi gürgen (Carpinus betulus L.) fidanlarında klorofil miktarları tespit edilmiştir. Çalışma sonucunda yükseltiye bağlı olarak Çamlıhemşin ve Maçka populasyonlarının klorofil miktarı bakımından istatistiksel olarak farklılık gösterdiği, Çaykara ve Espiye populasyonlarının ise istatistiksel olarak farklılık göstermediği ortaya koyulmuştur. Çalışmamızda ise tohumların elde edildiği farklı yükseltideki lokasyonların ekolojik özellikleri her ne kadar farklılık gösterse de klorofil değerleri arasında farklılıkların bulunmamasının, gerek genetik yapıdaki benzerlik durumu ve fidanların aynı yetişme ortamı koşullarında 
büyümesinden gerekse ekolojik özelliklerdeki değişimin klorofil değerinde farklılık oluşturacak derece etkili olmadığından kaynaklı olabileceği düşünülmektedir.

Yüzyıllar içerisinde yeryüzünde yaşanan hızlı değişim sürecinde doğa birçok yönden olumsuz etkilenmekte, tahrip olmakta ve ekolojik dengelerde bozulmalar meydana gelmektedir. Bütün bu olumsuz değişimlerden bitkilerde oldukça fazla etkilenmiş ve bitki sağlığı ve sürdürülebilirliği konusunda çalışmalar önemli hale gelmiştir. Bitkilerde klorofil miktarı tayini, bitkinin su stresinin belirlenmesi (Demirel vd., 2010; Kulaç, 2010), soğuğa toleransının belirlenmesi (Rose ve Haase, 2002; Perks vd., 2004; Çolak, 2012), ozon zararının tespiti (Knudson, 1977) gibi birçok uygulama alanlarında kullanılabilmektedir. Bu nedenle klorofil miktarının tespiti ile bitkilerdeki farklı özelliklerinin daha pratik olarak ortaya konulmasına yönelik çalışmalar arttırılmalı ve geliştirilerek devamlılığına katlı sağlanmalıdır.

\section{Kaynaklar}

1. Anşin, R., Özkan, C.Ö. (2006). Tohumlu Bitkiler (Spermatophytha) Odunsu Taksonlar, KTÜ Orman Fakültesi, Genel Yayın No: 167, Fakülte Yayın No: 19, Trabzon.

2. Aragon, G., Martínez, I., García, A. (2012). Loss of epiphytic diversity along a latitudinal gradient in southern Europe. Sci. Total Environ, 426, 188-195.

3. Atar, F., Güney, D., Hatipoğlu, E., Turna, İ. (2013). Determination of chlorophyll content hornbeam (Carpinus betulus L.) seedlings obtained from seed of different altitudes, International Caucasian Forestry Symposium, 147-151, 24-26 October 2013, Artvin

4. Atar, F., Turna, İ. (2018). Fruit and seedling diversity among sweet chestnut (Castanea sativa Mill.) populations in Turkey, Sumarski List, 11-12, 611-619.

5. Atar, F., Bayraktar, A., Yıldırım, N., Turna, İ., Güney, D. (2020). Fruit and seed diversity of Smilax excelsa in the Black Sea Region, Turkey. Turkish Journal of Forestry Research, 7, 1-8.

6. Bobrov, E.G. (1970). Carpinus L., In Flora of the U.S.S.R., Keter Press, Jerusalem, Israel, ed. N. Landau, 5, 202-207.

7. Browicz, G. (1982). Chronology of Trees and Shrubs in South-west Asia and Adjacent Regions. Polish Scientific Publishers, Warszawa-Poland, 172 pages.

8. Cetin, M. (2017). Change in amount of chlorophyll in some interior ornamental plants. Kastamonu University Journal of Engineering and Sciences, 3(1), 11-19.

9. Cetin, M., Sevik, H. (2016). Measuring the impact of selected plants on indoor $\mathrm{CO}_{2}$ concentrations. Pol. J. Environ. Stud., 25(3), 973-979.

10. Cetin, M., Topay, M., Kaya, L.G., Yılmaz, B. (2010). Efficiency of bioclimatic comfort in landscape planning process: case of Kutahya. Suleyman Demirel University, Journal of Forest Faculty Serial A: 83-95.

11. Çolak, D. (2012). Sarıçam (Pinus sylvestris L.), Anadolu Karaçamı (Pinus nigra Arn. subsp. pallasiana (Lamb.) Holmboe) ve Toros Sedirinde (Cedrus libani A. Rich.) Don Stresi Üzerine Bir Araştırma. Yüksek Lisans Tezi, Karadeniz Teknik Üniversitesi, Trabzon, Türkiye.

12. Demirci, A. (2006). Silvikültürün Temel İlkeleri, KTÜ Orman Fakültesi, Ders Notları Serisi No: 83, Trabzon.

13. Demirel, K., Genç, L., Çamoğlu, G., Aşık, Ş. (2010). Assessment of water stress using chlorophyll readings and leaf water content for watermelon. Journal of Tekirdă̆ Agricultural Faculty, 7(3), 155162.

14. Fallahchai, M.M., Özel, H.B., Payam, H. (2013). The comparison of the natural stands quantitative characteristics in managed and non-managed areas in caspian sea coastal forests. Bartın Orman Fakültesi Dergisi, 15(1), 1-10.

15. Gianoli, E., Valladares, F. (2010). Global change and the evolution of phenotypic plasticity in plants. Ann. NY. Acad. Sci. 1206, 35-55.

16. Gond, V., DePury, D.G.G., Veroustraete, F., Ceulemans, R. (2012). Seasonal variations in leaf area index, leaf chlorophyll, and water content; scaling-up to estimate fAPAR and carbon balance in a multilayer, multispecies temperate forest. Tree Physiology, 19, 673-679.

17. Guerin, G.R., Wen, H.X., Lowe, A.J. (2012). Leaf morphology shifts linked to climate change. Biol. Lett. 8, 882-886.

18. Güney, D., Atar, F., Turna, İ., (2016a). Adi Gürgen (Carpinus betulus L.)’nin Süs Bitkisi Olarak Değerlendirilmesi, VI. Süs Bitkileri Kongresi, 73, 19-22 Nisan, Antalya.

19. Güney, D., Turna, H., Turna, İ., Kulaç, Ş., Atar, F., Filiz E. (2016b). Variations within and among populations depending on some leaf characteristics of oriental beech (Fagus orientalis Lipsky). Biological Diversity and Conservation, 9, 1-9. 
20. Herrera, C.M., Bazaga, P. (2013). Epigenetic correlates of plant phenotypic plasticity: DNA methylation differs between prickly and nonprickly leaves in heterophyllous Ilex aquifolium (Aquifoliaceae) trees. Bot. J. Linn. Soc. 171: 441-452.

21. Hora, B. (1981). The Oxford Encyclopedia of Trees of the World, Oxford Unviersity Press, Oxford, U.K., 288 pages.

22. Kaya, L.G., Çetin, M., Doygun, H. (2015). A holistic approach in analyzing the landscape potential: Porsuk Dam Lake and its environs. Turkey. Fresenius Environmental Bulletin, 18(8), 1525-1533.

23. Knudson, L.L., Tibbitts, T.W., Edward, G.E. (1977). Measurement of ozone injury by determination of chlorophyll concentration, Plant Physiology. 60, 606-608.

24. Krüssmann, G. (1984). Manual of Cultivated Broad-Leaved Trees and Shrubs, Vol. 1, A-D, Timber Press, Inc, Portland, Oregon, U.S.A., 448 pages.

25. Kulaç, Ş. (2010). Sarıçam (Pinus sylvestris L.) tohumlarında ve fidanlarında orijinlere bağlı olarak su stresinin morfolojik ve fizyolojik özelliklere üzerindeki etkisinin araştırılması, Doktora Tezi, Karadeniz Teknik Üniversitesi, Trabzon, Türkiye.

26. Leingartner, A., Hoiss, B., Krauss, J., Dewenter, I.S. (2014). Combined effects of extreme climatic events and elevation on nutritional quality and herbivory of alpine plants. PloS one 9(4), e93881.

27. Lepeduš, H., Cesar, V., Suver, M. (2003). The annual changes of choloroplast pigments content in current-and previous-year needles of norway spruce (Picea abies L. Karst.) exposed to cement dust pollution. Acta Botanica Croatica, 62(1), 27-35.

28. Matesanz, S., Gianoli, E., Valladares, F. (2010). Global change and the evolution of phenotypic plasticity in plants. Ann. N.Y. Acad. Sci., 1206, 35-55.

29. Miner, B.G., Sultan, S.E., Morgan, S.G., Padilla, D.K., Relyea, R.A. (2005). Ecological consequences of phenotypic plasticity. Trends. Ecol. Evol., 20, 685-692.

30. Nascimbene, J., Marini, L. (2015). Epiphytic lichen diversity along elevational gradients: biological traits reveal a complex response to water and energy. Journal of Biogeography, 42, 1222-1232.

31. Onckelen H.A.V, Caubergs, R., Greef, J.A.D (1977). Effect of light treatment and endogenous growth hormones on $\alpha$-and $\beta$-amylase activities in cotyledons of Phaseolus vulgaris L., Plant and Cell Physiology, 18(5), 1029-1040.

32. Özel, HB., Ertekin, M. (2012). The change of stand structure in Uludağ fir (Abies nordmanniana subsp. bornmuelleriana Mattf.) forests along an altitudinal gradient. Kastamonu University Journal of Forestry Faculty, 12(3), 96-104.

33. Perks, M.P., Osborne, B.A., Mitchell, D.T. (2004). Rapid predictions of cold tolerance in douglas-fir seedlings using chlorophyll fluorescence after freezing, New Forests, 28(1), 49-62.

34. Pinfield, N.J., Stobart, A.K. (1972). Hormonal regulation of germination and early seedling development in Acer pseudoplatanus (L.). Planta, 104, 134-145.

35. Pipinis, E., Milios, E., Kiamos, N., Mavrokordopoulou, O., Simiris, P. (2012). Effect of stratification and pre-treatment with gibberellic acid on seed germination of two Carpinus species, Seed Science and Technology, 40, 21-31.

36. Rose, R., Haase, D. (2002). Chlorophyll fluorescence and variations in tissue cold hardiness in response to freezing stress in Douglas-Fir seedlings. New Forests, 23(2), 81-96.

37. Ryc, M., Lewak, S. (1982). Hormone interactions in the formation of the photosynthetic apparatus in dormant and stratified apple embryos, Z. Pjlanzenphysiol. Bd., 107, 15-24.

38. Shafiei, A.B, Akbarinia, M., Jalali, G., Hosseini, M. (2010). Forest fire effects in beech dominated mountain forest of Iran. Forest Ecology and Management, 259, 2191-2196.

39. Shen, H.H., Tang, Y.H., Muraoka, H., Washitani, I. (2008). Characteristics of leaf photosynthesis and simulated individual carbon budget in Primula nutans under contrasting light and temperature conditions. J. Plant Res., 121, 191-200.

40. Soares, L.H., Neto, D.D., Fagan, E.B., Teixeira, W.F., dos Reis, M.R., Reichardt, K. (2016). Soybean seed treatment with micronutrients, hormones and amino acids on physiological characteristics of plants. African Journal of Agricultural Research, 11(35), 3314-3319.

41. Taner, S., Sade, B. (2005). Low temperature effect of cereal (A review). Journal of Crop Research, 2, 19-28.

42. Tepe, Ş., Ellialtıoğlu, Ş., Yenice, N., Tıpırdamaz, R. (2002). Obtaining poliploid Mint (Mentha longifolia L.) plants with in vitro colchicine treatment. Akdeniz Üniversitesi Ziraat Fakültesi Dergisi, 15(2), 63-69.

43. Turna İ. (2017). Kent Ormancılı̆̆ (Kentsel Yeşil Alanlar), Karadeniz Teknik Üniversitesi, Trabzon.

44. Yaltırık, F. (1982). Flora of Turkey and Aest Eagen Island, Universty Press, Edinburgh., Ed. P.H. Davis, 7, 684. 